\title{
Offspring size at birth and maternal risk for cardiovascular disease: a systematic review and meta-analysis
}

\author{
Prabha Andraweera ${ }^{1}$, Zohra Lassi ${ }^{2}$, Maleesa Pathirana ${ }^{1}$, Anna Ali ${ }^{3}$, Gus Dekker ${ }^{4}$, Claire \\ Roberts $^{5}$, and Margaret Arstall ${ }^{6}$ \\ ${ }^{1}$ The University of Adelaide \\ ${ }^{2}$ Robinson Research Institute \\ ${ }^{3}$ Basil Hetzel Institute for Medical Research \\ ${ }^{4}$ The University of Adelaide Adelaide Medical School \\ ${ }^{5}$ University of Adelaide \\ ${ }^{6}$ Lyell McEwin Hospital
}

August 22, 2020

\begin{abstract}
Background: Offspring size at birth is known to be associated with maternal cardiovascular disease (CVD) risk. Low birthweight (LBW), small for gestational age (SGA) and intrauterine growth restriction (IUGR) are all used to define infants considered small at birth. Objectives: To determine whether women who give birth to SGA/LBW/IUGR infants have higher levels of cardio-metabolic risk factors compared to women who give birth to average for gestational age infants or women. Search strategy: We performed a systematic literature search using PubMed, Embase and CINAHL. Selection criteria: Studies that compared cardio-metabolic risk factors in women who gave birth to SGA/LBW/IUGR infants compared to a control group. Data collection and analysis: Two independent authors screened and extracted data. Meta-analysis was performed on Review Manager 5.3. Main results: The meta-analysis showed a significantly increased CVD mortality among women who gave birth to SGA infants compared to AGA infants (relative risk 1.45, 95\% confidence interval (CI) 1.40 to $1.52 ; 2,584,533$ participants, three studies; heterogeneity: Chi2 $\mathrm{P}=0.48 ; \mathrm{I} 2=0 \%$ ). Women who gave birth to growth restricted infants had significantly higher mean BMI $(1.72 \mathrm{~kg} / \mathrm{m} 2,95 \%$ CI 0.97 to $2.47 ; 77$ participants, two studies; heterogeneity: $\mathrm{Chi} 2 \mathrm{P}=0.35 ; \mathrm{I} 2=0 \%)$, and higher total mean cholesterol levels $(0.32 \mathrm{mmol} / 1,95 \%$ CI 0.13 to 0.50; 77 participants, two studies; heterogeneity: Chi2 $\mathrm{P}=0.69$; I2=0\%) compared to women who had uncomplicated pregnancies. Conclusions: Women who give birth to small infants are at increased risk of CVD. Postpartum screening for CVD risk factors will help identify those at risk.
\end{abstract}

\section{INTRODUCTION}

Increasing evidence demonstrates an association between offspring size at birth and maternal cardiovascular disease (CVD) risk. A meta-analysis of six studies, published in 2007, showed an inverse relationship between offspring weight at birth and maternal CVD mortality (pooled adjusted hazard ratio (aHR) of 0.75 (95\% confidence interval (CI): 0.67 to 0.84 ) for 1-standard deviation (SD) increase in offspring birthweight) ${ }^{1}$. A subsequent study of 1,400,383 women showed 1.8 times higher risk of mortality from CVD among women who gave birth to low birth weight (LBW, birthweight $<2500 \mathrm{~g}$ ) infants compared to those who gave birth to normal birthweight (2500-3999g) infants (aHR: 1.85; 95\% CI 1.57 to 2.18$)^{2}$. Recent studies have shown similar associations for women who give birth to infants diagnosed as small for gestational age (SGA) at birth compared to women who give birth to average for gestational age (AGA) infants ${ }^{3,4}$. The terms "LBW" and "SGA" are both used to define infants considered small at birth. Although many infants classified as SGA or LBW have intrauterine growth restriction (IUGR) and many growth restricted infants are born with LBW 
or are classified as SGA, the three terms are not synonymous ${ }^{5}$. LBW simply means birthweight $<2.5 \mathrm{~kg}$ and at present, the definition is mostly used in developing countries where gestational age is often uncertain, and reliable population centiles let alone customized centiles are not available. SGA means birthweight $<$ $10^{\text {th }}$ centile for a given gestational age. Population centiles use birthweight centiles on a whole population, irrespective of maternal ethnicity, height and weight and customized centiles provide birthweight centiles customized for maternal ethnicity, height, weight and parity. Infants with IUGR are those that do not achieve fullin utero growth potential because of genetic or environmental factors and are at increased risk for significant morbidity and mortality compared to infants with normal in utero growth. Infants born growth restricted are at increased risk of CVD and type 2 diabetes mellitus in adulthood and "programming in response to an adverse intrauterine environment" as well as genetic and environmental influences are proposed to contribute to the risk. However, associations between offspring SGA/LBW and maternal CVD risk cannot be explained to a large extent by programming. This, however, can be explained by the presence of genetic polymorphisms that influence both fetal growth and CVD as well as by adverse environmental influences that operate across the parental life course and affect both offspring and adult health. To our knowledge there is no systematic review and meta-analysis that has assessed maternal risk for CVD using data from studies reporting on the three common classifications of offspring size at birth. Therefore, the aim of this study was to identify the relationship between offspring size at birth and maternal CVD risk based on different classifications of offspring size at birth.

\section{METHODS}

\section{Data sources and Search strategy}

This systematic review and meta-analysis was conducted in accordance with the Meta-analysis Of Observational Studies in Epidemiology (MOOSE) guidelines ${ }^{6}$. The review protocol is registered with PROSPERO (CRD42019138399). We searched the electronic databases, MEDLINE, EMBASE, CINHAL, and Web of Science with an end of search date of May 6, 2019. Subsequently, we updated the literature search to include all relevant articles published until May 31, 2020. The search was conducted by ZL. The search strategy is detailed in the supplementary file. Bibliographies of previously conducted systematic reviews and meta-analyses on closely related topics, and eligible studies were checked for additional studies. Two reviewers independently screened the titles and abstracts of studies (PA, MP, AA, ZL). Data extraction was also conducted by two reviewers independently (PA, ZL). Disagreements were resolved by discussion within the team.

\section{Study selection and data extraction}

Studies were considered eligible if they compared CVD risk factors between the following comparison groups: (1) women who gave birth to SGA infants compared to women who gave birth to AGA infants, (2) women who gave birth to LBW infants (birthweight [?]2500g) compared to women who gave birth to normal birthweight (birthweight $>2500 \mathrm{~g}$ ) infants, (3) women who gave birth to infants diagnosed with IUGR with women who gave birth to non-IUGR infants. Studies that reported an association between maternal CVD mortality/CVD occurrence and offspring size at birth were also included. SGA was defined as birthweight below the $10^{\text {th }}$ population or customised birthweight centile; LBW was defined as birthweight below 2500g; and IUGR was defined as true documented intrauterine growth restriction or an accepted surrogate diagnosis of IUGR, i.e. birthweight $<5^{\text {th }}$ population or customised birthweight centile and abnormal umbilical artery Doppler results. Definitions of SGA/LBW and IUGR used in the included studies are detailed in table 1. The outcomes assessed were systolic blood pressure (SBP), diastolic blood pressure (DBP), body mass index (BMI), total cholesterol, low density lipoprotein cholesterol (LDL), high density lipoprotein cholesterol (HDL), triglycerides, fasting blood glucose (BG), fasting insulin, and CVD mortality. Data from studies classifying infants as SGA, LBW and IUGR were analysed as separate groups. Studies that did not have the above definitions, those that did not define the comparison groups and those that compared women who gave birth to small babies with another risk group were excluded. All selected studies were published in peer-reviewed journals, undertaken in humans, and published in English. 


\section{Statistical analysis}

The meta-analysis was performed using the RevMan software (Review Manager Version 5.3). For the outcomes of SBP, DBP, BMI, and lipids, Mean Difference (MD) and the $95 \%$ confidence interval (CI) were calculated using a fixed effects or random effects model. Where heterogeneity was substantially high $\left(\mathrm{Chi}^{2}\right.$ $\mathrm{P}$ value of $<0.1$ and $\mathrm{I}^{2}$ value of $>30 \%$ ), we reported the outcomes using random-effect mode, otherwise the outcomes were reported using a fixed effect model. When standard error of the mean (SEM) or CI of means were reported instead of the SD, the SEM/CI were converted to SD. When median and intra-quartile range (IQR) were reported, the results were extracted as reported and are detailed in table 1 . For the metaanalyses on CVD mortality, the number of deaths due to CVD and the total number of participants were used in the meta-analysis to analyse the risk difference. If the study reported the number as a percentage, then the number of participants/events was calculated based on the total sample size for each group. The methodological quality was assessed using the National Heart, Lung and Blood Institute (NHLBI) Quality Assessment Tool for Observational Cohort and Cross-Sectional Studies.

\section{RESULTS}

A total of 21,884 articles were identified by the search, of which 520 were eligible for full text review (Figure 1) and a further 11 were identified from bibliographic searches. Of these, 18 studies were included in the review, and seven were included in the meta-analysis. The reasons for excluding 513 papers are detailed in figure 1. The quality assessment showed that no studies were of low quality.

\section{Maternal CVD risk factors according to the delivery of a SGA vs AGA infant}

Four studies reported on conventional CVD risk factors between women who gave birth to SGA compared to AGA infants (table 1) ${ }^{7-10}$. Two studies classified SGA as birthweight $<10^{\text {th }}$ population centile ${ }^{7,10}$, one

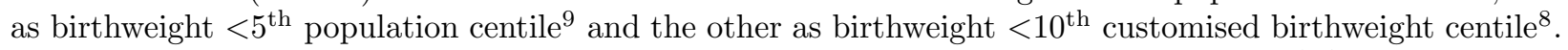
Two studies were conducted on normotensive women who gave birth to SGA infants ${ }^{8,9}$. Four studies compared SBP and DBP between women who gave birth to SGA infants compared to those who gave birth to AGA infants. Of these, two studies reported significantly higher $\mathrm{SBP}^{7}, 9$ and one study reported significantly higher $\mathrm{DBP}^{7}$ among women who gave birth to SGA infants after adjusting for confounding factors (table 1). BMI was reported in one study which found no significant difference between the two comparison groups ${ }^{7}$. Three studies compared lipids between the two study groups ${ }^{7,9,10}$. Of these, two reported significantly higher serum triglycerides ${ }^{9,10}$ and one significantly higher LDL cholesterol ${ }^{9}$ among women who gave birth to SGA infants compared to those who gave birth to AGA infants (table 1). Blood glucose was reported in three studies ${ }^{7,9,10}$ and insulin level in one study ${ }^{9}$. All results on blood glucose and insulin were not statistically significantly different between the two comparison groups (table 1). Results of two studies were included in the meta-analyses on $\mathrm{SBP}$ and $\mathrm{DBP}^{7,8}$. The pooled analyses did not show a significant difference in SBP or DBP between women who gave birth to SGA compared to AGA infants (Supplementary figures 1 and 2).

\section{Maternal CVD risk factors according to the delivery of a low birth weight vs normal birth weight infant}

Two studies reported on maternal CVD risk factors based on birthweight of offspring ${ }^{11,12}$ (table 1). Catov and colleagues compared blood pressure, BMI, lipids, fasting blood glucose and fasting insulin between women who gave birth to low birth weight vs normal birthweight infants and reported significantly higher SBP and significantly lower BMI among women who gave birth to LBW infants ${ }^{11}$ (table 1). Lawlor and colleagues assessed the relationship between birthweight of offspring and age adjusted BMI, SBP, LDL, HDL and triglyceride levels in a cohort of 3265 women $^{12}$. Their study demonstrated that for each increase of $1 \mathrm{~kg}$ in offspring birthweight, the logarithm of SBP decreased by 1.79 and BMI increased by $0.74^{12}$ (table 1). The results of the two studies reporting on maternal CVD risk factors based on birthweight of offspring could not be included in the meta-analyses.

Maternal CVD risk factors according to the delivery of an infant with intrauterine growth 


\section{restriction vs women who experienced uncomplicated pregnancies}

Two studies compared maternal CVD risk factors between women who gave birth to growth restricted infants and women who had uncomplicated pregnancies ${ }^{13,14}$ (table 1). Of these one study was conducted on normotensive women who gave birth to growth restricted infants ${ }^{14}$. Manten and colleagues reported a significantly higher serum total cholesterol level among women who gave birth to infants diagnosed as having IUGR compared to women who had uncomplicated pregnancies but the difference was not significant after excluding women with chronic hypertension, smokers and those with BMI $>30 \mathrm{~kg} / \mathrm{m}^{213}$ (table 1). Yinon and colleagues compared BMI, total cholesterol, LDL, HDL, blood glucose and insulin in women who gave birth to growth restricted infants and those who had uncomplicated pregnancies ${ }^{14}$. Both studies were included in meta-analyses on BMI, total cholesterol, HDL cholesterol and triglycerides ${ }^{13,}{ }^{14}$. The pooled analyses showed that women who gave birth to infants diagnosed as having IUGR had significantly higher mean BMI $\left(1.72 \mathrm{~kg} / \mathrm{m}^{2}, 95 \%\right.$ CI 0.97 to $2.47 ; 77$ participants, heterogeneity: $\mathrm{Chi}^{2} \mathrm{P} 0.35 ; \mathrm{I}^{2}=0 \%$, figure $\left.2 \mathrm{~A}\right)$, and higher total mean cholesterol levels $\left(0.32 \mathrm{mmol} / 1,95 \%\right.$ CI 0.13 to $0.50 ; 77$ participants, heterogeneity: Chi ${ }^{2}$ $\mathrm{P} 0.69 ; \mathrm{I}^{2}=0 \%$ ) compared to women who had uncomplicated pregnancies (figure $\left.2 \mathrm{~B}\right)^{13}, 14$.

\section{Association between offspring size at birth and maternal cardiovascular disease mortality}

Nine large data linkage studies assessed the association between offspring birthweight/SGA and maternal cardiovascular disease mortality ${ }^{1,2,4,15-20}$ and one assessed the association between delivery of a SGA infant and the occurrence of maternal $\mathrm{CVD}^{3}$ (table 2). Of the studies reporting on maternal CVD mortality, two studies demonstrated aHRs of 2.0 and 2.2 for each $1 \mathrm{~kg}$ decrease in offspring birthweight ${ }^{15,18}$ and five studies demonstrated aHRs between 0.75 and 0.89 for each 1 SD increase in offspring birthweight ${ }^{1,2,4,19,20}$ (table 2). Four studies assessed maternal CVD mortality in relation to giving birth to a SGA vs AGA infant and reported aHRs between 1.31 - 3.5 among women who gave birth to SGA compared to AGA infants ${ }^{2-4,16}$ (table 2). A large data linkage study of 812,732 women demonstrated that, compared to women who gave birth to non-SGA infants, the aHR for first occurrence of CVD among women who gave birth to moderately SGA infants (birthweight between $3^{\text {rd }}-10^{\text {th }}$ percentile) was 1.36 (95\% CI, 1.23 to 1.49 ) and among women who gave birth to severe SGA infants (birthweight $<3^{\text {rd }}$ centile) was 1.66 (95\% CI, 1.47 to 1.87$)^{3}($ table 2 ). That study also showed a linear increase in aHR for first occurrence of CVD of 1.42 (95\% CI, 1.30 to 1.54), 1.65 (95\% CI, 1.34 to 2.03$)$ and 2.42 (95\% CI, 1.52 to 3.85$)$ for women who gave birth to one SGA infant, two SGA infants and three SGA infants respectively, compared to women who gave birth to non-SGA infants ${ }^{3}$ (table 2). Three studies were included in the meta-analysis on CVD mortality among women who gave birth to SGA compared to AGA infants, providing data on 2,584,533 individuals (figure 3) ${ }^{2,4,16}$. The pooled data shows a significantly increased CVD mortality among women who gave birth to SGA infants compared to those who gave birth to AGA infants ( $\mathrm{RR} 1.45,95 \%$ CI 1.40 to 1.52 ); heterogeneity: $\mathrm{Chi}^{2} \mathrm{P}^{0.48} \mathrm{I}^{2}=$ $0 \%$ )

\section{DISCUSSION}

This systematic review demonstrates an inverse relationship between offspring birthweight and maternal CVD mortality. Our meta-analysis shows an approximately 1.5 times increased risk of death from CVD among women who gave birth to SGA infants compared to women who gave birth to AGA infants. The meta-analyses also demonstrated that BMI and total cholesterol levels were higher among women who gave birth to infants diagnosed as having IUGR compared to women who experienced uncomplicated pregnancies.

The evidence for the association between offspring birthweight and maternal CVD mortality was provided by eight large data linkage studies conducted in six countries ${ }^{1,2,4,15-20}$. All studies provided consistent findings and showed a reduction in offspring birthweight associated with increased maternal CVD mortality or an increase in offspring birthweight associated with a reduction in maternal CVD mortality. All of these results were shown to be significant after adjusting for relevant confounding factors. All studies that compared CVD mortality among women who gave birth to SGA vs AGA infants demonstrated a HR between 1.31-3.5 for women who gave birth to SGA infants after adjusting for relevant confounding factors ${ }^{2,4,16}$ while the pooled analysis showed a RR of 1.45 with no significant heterogeneity among the three studies $\left(\mathrm{Chi}^{2} \mathrm{P} 0.48\right.$, 
$\left.\mathrm{I}^{2}=0 \%\right)$

A few mechanistic pathways could be implicated in the association between offspring size at birth and maternal CVD risk. One plausible mechanism is the genetic contribution. CVD has a substantial genetic component, and polymorphisms in several genes encoding glucokinase ${ }^{21}$, angiogenic pathway ${ }^{22}$, angiotensinogen ${ }^{23}$, clotting factors ${ }^{24}$ are associated with both restricted fetal growth and risk of CVD. The evidence for a genetic link between offspring birthweight and maternal risk for CVD is supported by studies that have shown an association between offspring birthweight and parental CVD risk. Li and colleagues (2010) in a data linkage study of 1,400,383 primigravida and their spouses demonstrated an adjusted HR of 1.13 (95\% CI: 1.03 to 1.24) among fathers of low birth weight infants ${ }^{2}$. Consistent with the above findings, Davey Smith and colleagues reported an adjusted HR of 0.94 (95\% CI: 0.89 to 0.99) for CVD mortality among fathers for each one SD increase in offspring birthweight ${ }^{1}$. The theory for a genetic association is further strengthened by a number of multigenerational studies, reporting a strong association between birthweight of grandchild and CVD mortality in grandparents (HR of $0.86,95 \%$ CI: 0.83 to 0.89 for $1 \mathrm{~kg}$ increase in birthweight ${ }^{25}$ and HR between 0.95-0.99 for one quintile increase in birthweight $)^{26}$. The genetic theory is further supported by a recent study of 1,353,956 births that showed an association between offspring birthweight and CVD mortality among aunts and uncles (HRs between 0.90 (95\% CI 0.86 to 0.95 ) and 0.93 (95\% CI 0.91 to 0.95 ) for one SD increase in offspring birthweight) ${ }^{4}$.

Another plausible mechanism linking offspring size at birth with maternal CVD risk is shared environmental and behavioural factors. For example, smoking is a risk factor for both low birthweight and CVD. Women who smoke during pregnancy are at a higher risk of giving birth to growth restricted infants. These women are likely to continue smoking, increasing their subsequent risk of CVD. Partners of women who smoke are likely to be smokers themselves and hence would also be at higher risk of developing CVD. Hence, the association between offspring size at birth and paternal CVD risk could also be explained by environmental and behavioural factors shared by both parents.

The third plausible theory on the association between offspring size at birth and maternal CVD risk suggests maternal/fetal nutritional factors and intrauterine programming as a potential contributor. Women who themselves had poor intrauterine growth and LBW tend to give birth to SGA infants ${ }^{27}$. This association may be mediated via poor placentation or effects of intrauterine programming. Pregnancy may also act as a "second hit" for women who were born small ${ }^{28}$. Pregnancy is increasingly being considered as a physiological stress test for the female cardiovascular system and those who were born "small", when exposed to a second hit of pregnancy, may develop pregnancy complications including intrauterine growth restriction ${ }^{28}$.

This systematic review and meta-analysis demonstrates evidence of an association between offspring size at birth and maternal CVD mortality. However, there was insufficient data to compare conventional CVD risk factors among women who gave birth to small babies compared to women who have birth to AGA infants due to the limited number of studies reporting on the outcomes. Pooled evidence from two small studies demonstrate higher BMI and higher serum total cholesterol levels among women who gave birth to growth restricted infants compared to women who had uncomplicated pregnancies. However, the sample sizes in these analyses were very small. Hence, larger studies are required for meaningful comparisons. In addition, only few studies reported on cohorts of normotensive women who gave birth to small infants, hence, confounding due to maternal gestational hypertension and preeclampsia is a real possibility. Another limitation in the current literature is the paucity of information on women's age in studies reporting on the associations between offspring size at birth and maternal CVD mortality. The reported follow up periods of the included studied varied from 4 years to $\sim 47$ years postpartum. Hence, some of the studies reported CVD mortality among old aged women.

Overall, this systematic review and meta-analysis shows that women who give birth to SGA infants are at higher risk of CVD mortality compared to women who give birth to AGA infants. Genetic, environmental and behavioural factors could all contribute to this association. Larger well characterised cohorts with the ability to distinguish CVD risk factor profiles at a young age between normotensive and hypertensive women who give birth to SGA infants are required to identify the true association between offspring size at birth 
and maternal risk for CVD.

\section{Disclosure of interests}

The authors declare no conflicts of interest

\section{Contribution to authorship}

PHA, ZSL, MAA, CTR and GAD conceived and designed the study. ZSL conducted the search. PHA, ZSL, MMP and AA screened the papers and extracted data. ZSL conducted the meta-analysis. PHA wrote the manuscript. All authors read and approved the final version of the manuscript.

\section{Details of ethics approval}

Since this study was a systematic review and meta-analysis, ethics approval was not required.

Funding: NHMRC Peter Doherty Early Career Fellowship awarded to PHA (GNT (GNT1090778), NHMRC Public Health Early Career Fellowship awarded to ZSL (GNT1141382). CTR is supported by a NHMRC Investigator Grant (GNT1174971) and a Matthew Flinders Fellowship from Flinders University.

\section{REFERENCES}

1. Davey Smith G, Hypponen E, Power C, Lawlor DA. Offspring birth weight and parental mortality: prospective observational study and meta-analysis. American journal of epidemiology. 2007 Jul $15 ; 166(2): 160-9$.

2. Li CY, Chen HF, Sung FC, Chen CC, Lu TH, Yang CH, et al. Offspring birth weight and parental cardiovascular mortality. International journal of epidemiology. 2010 Aug;39(4):1082-90.

3. Ngo AD, Roberts CL, Chen JS, Figtree G. Delivery of a Small-For-Gestational-Age Infant and Risk of Maternal Cardiovascular Disease-A Population-Based Record Linkage Study. Heart, lung \& circulation. $2015 \mathrm{Jul} ; 24(7): 696-704$.

4. Shaikh F, Kjolllesdal MK, Carslake D, Stoltenberg C, Davey Smith G, Naess O. Birthweight in offspring and cardiovascular mortality in their parents, aunts and uncles: a family-based cohort study of 1.35 million births. International journal of epidemiology. 2019 Jul 20.

5. Gardosi J. Intrauterine growth restriction: new standards for assessing adverse outcome. Best practice \& research Clinical obstetrics \& gynaecology. 2009 Dec;23(6):741-9.

6. Stroup DF, Berlin JA, Morton SC, Olkin I, Williamson GD, Rennie D, et al. Meta-analysis of observational studies in epidemiology: a proposal for reporting. Meta-analysis Of Observational Studies in Epidemiology (MOOSE) group. Jama. 2000 Apr 19;283(15):2008-12.

7. Fraser A, Nelson SM, Macdonald-Wallis C, Cherry L, Butler E, Sattar N, et al. Associations of pregnancy complications with calculated cardiovascular disease risk and cardiovascular risk factors in middle age: the Avon Longitudinal Study of Parents and Children. Circulation. 2012 Mar 20;125(11):1367-80.

8. Hillman SL, Kubba T, Williams DJ. Delivery of small-for-gestational-age neonate and association with early-onset impaired maternal endothelial function. Ultrasound in obstetrics \& gynecology : the official journal of the International Society of Ultrasound in Obstetrics and Gynecology. 2017 Jan;49(1):150-4.

9. Kanagalingam MG, Nelson SM, Freeman DJ, Ferrell WR, Cherry L, Lowe GD, et al. Vascular dysfunction and alteration of novel and classic cardiovascular risk factors in mothers of growth restricted offspring. Atherosclerosis. $2009 \mathrm{Jul} ; 205(1): 244-50$.

10. King TF, Bergin DA, Kent EM, Manning F, Reeves EP, Dicker P, et al. Endothelial progenitor cells in mothers of low-birthweight infants: a link between defective placental vascularization and increased cardiovascular risk? The Journal of clinical endocrinology and metabolism. 2013 Jan;98(1):E33-9. 
11. Catov JM, Newman AB, Roberts JM, Sutton-Tyrrell KC, Kelsey SF, Harris T, et al. Association between infant birth weight and maternal cardiovascular risk factors in the health, aging, and body composition study. Annals of epidemiology. 2007 Jan;17(1):36-43.

12. Lawlor DA, Davey Smith G, Ebrahim S. Birth weight of offspring and insulin resistance in late adulthood: cross sectional survey. BMJ (Clinical research ed). 2002 Aug 17;325(7360):359.

13. Manten GT, Sikkema MJ, Voorbij HA, Visser GH, Bruinse HW, Franx A. Risk factors for cardiovascular disease in women with a history of pregnancy complicated by preeclampsia or intrauterine growth restriction. Hypertension in pregnancy. 2007;26(1):39-50.

14. Yinon Y, Kingdom JC, Odutayo A, Moineddin R, Drewlo S, Lai V, et al. Vascular dysfunction in women with a history of preeclampsia and intrauterine growth restriction: insights into future vascular risk. Circulation. 2010 Nov 2;122(18):1846-53.

15. Davey Smith G, Hart C, Ferrell C, Upton M, Hole D, Hawthorne V, et al. Birth weight of offspring and mortality in the Renfrew and Paisley study: prospective observational study. BMJ (Clinical research ed). 1997 Nov 8;315(7117):1189-93.

16. Pariente G, Sheiner E, Kessous R, Michael S, Shoham-Vardi I. Association between delivery of a smallfor-gestational-age neonate and long-term maternal cardiovascular morbidity. International journal of gynaecology and obstetrics: the official organ of the International Federation of Gynaecology and Obstetrics. 2013 Oct;123(1):68-71.

17. Smith GC, Pell JP, Walsh D. Pregnancy complications and maternal risk of ischaemic heart disease: a retrospective cohort study of 129,290 births. Lancet (London, England). 2001 Jun 23;357(9273):2002-6.

18. Smith GD, Harding S, Rosato M. Relation between infants' birth weight and mothers' mortality: prospective observational study. BMJ (Clinical research ed). 2000 Mar 25;320(7238):839-40.

19. Smith GD, Sterne J, Tynelius P, Lawlor DA, Rasmussen F. Birth weight of offspring and subsequent cardiovascular mortality of the parents. Epidemiology (Cambridge, Mass). 2005 Jul;16(4):563-9.

20. Smith GD, Whitley E, Gissler M, Hemminki E. Birth dimensions of offspring, premature birth, and the mortality of mothers. Lancet (London, England). 2000 Dec 16;356(9247):2066-7.

21. Hattersley AT, Tooke JE. The fetal insulin hypothesis: an alternative explanation of the association of low birthweight with diabetes and vascular disease. Lancet (London, England). 1999 May 22;353(9166):1789-92.

22. Andraweera PH, Dekker GA, Thompson SD, Roberts CT. Single-nucleotide polymorphisms in the KDR gene in pregnancies complicated by gestational hypertensive disorders and small-for-gestational-age infants. Reproductive sciences (Thousand Oaks, Calif). 2012 May;19(5):547-54.

23. Zhang XQ, Varner M, Dizon-Townson D, Song F, Ward K. A molecular variant of angiotensinogen is associated with idiopathic intrauterine growth restriction. Obstetrics and gynecology. 2003 Feb;101(2):23742.

24. Kupferminc MJ, Eldor A, Steinman N, Many A, Bar-Am A, Jaffa A, et al. Increased frequency of genetic thrombophilia in women with complications of pregnancy. The New England journal of medicine. 1999 Jan 7;340(1):9-13.

25. Smith GC, Wood AM, White IR, Pell JP, Hattie J. Birth weight and the risk of cardiovascular disease in the maternal grandparents. American journal of epidemiology. 2010 Mar 15;171(6):736-44.

26. Naess O, Stoltenberg C, Hoff DA, Nystad W, Magnus P, Tverdal A, et al. Cardiovascular mortality in relation to birth weight of children and grandchildren in 500,000 Norwegian families. European heart journal. 2013 Nov;34(44):3427-36. 
27. Andraweera PH, Dekker G, Leemaqz S, McCowan L, Myers J, Kenny L, et al. Effect of Birth Weight and Early Pregnancy BMI on Risk for Pregnancy Complications. Obesity (Silver Spring, Md). 2019 Feb;27(2):237-44.

28. Cheong JN, Wlodek ME, Moritz KM, Cuffe JS. Programming of maternal and offspring disease: impact of growth restriction, fetal sex and transmission across generations. The Journal of physiology. 2016 Sep 1;594(17):4727-40.

\section{Figure Legends}

Figure 1: PRISMA flow diagram of study selection process

Figure 2: Cardio-metabolic risk factors between women who gave birth to infants with IUGR and women who had uncomplicated pregnancies

Figure 3: Cardiovascular disease mortality between women who gave birth to SGA infants and women who gave birth to AGA infants

Table 1 Published studies of the association between offspring size at birth and maternal cardiovascular disease risk factors

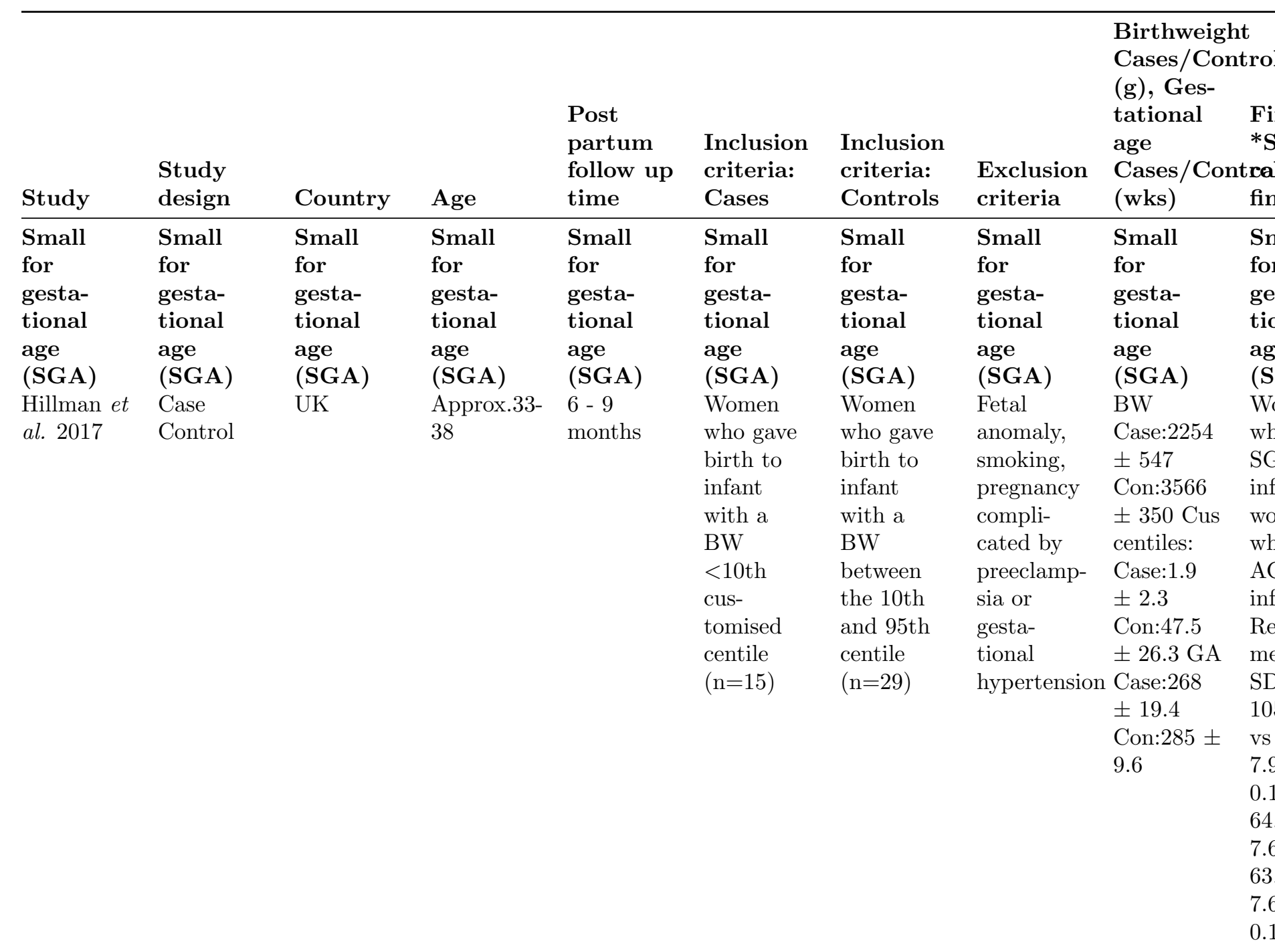




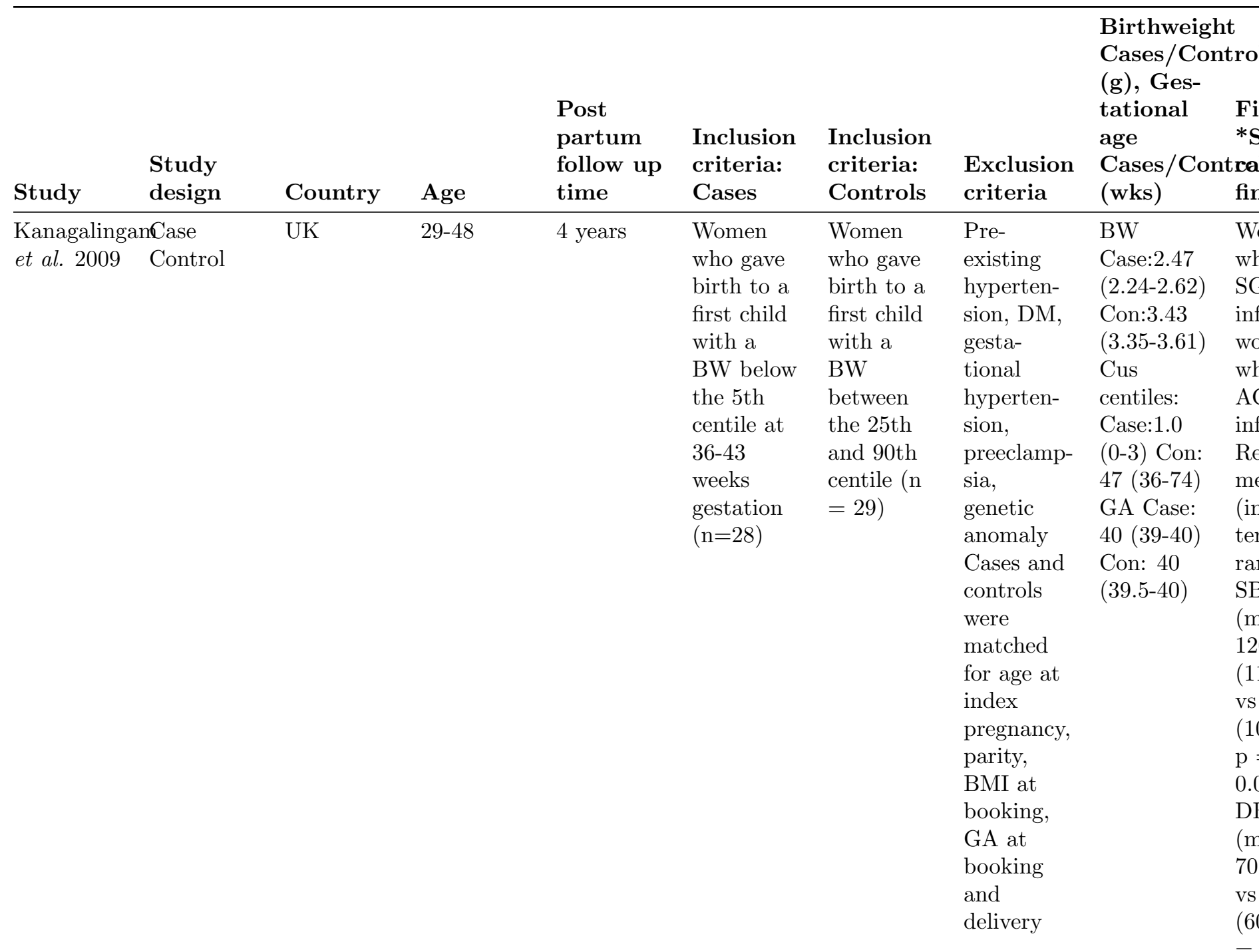




\begin{tabular}{|c|c|c|c|c|c|c|c|c|}
\hline Study & $\begin{array}{l}\text { Study } \\
\text { design }\end{array}$ & Country & Age & $\begin{array}{l}\text { Post } \\
\text { partum } \\
\text { follow up } \\
\text { time }\end{array}$ & $\begin{array}{l}\text { Inclusion } \\
\text { criteria: } \\
\text { Cases }\end{array}$ & $\begin{array}{l}\text { Inclusion } \\
\text { criteria: } \\
\text { Controls }\end{array}$ & $\begin{array}{l}\text { Exclusion } \\
\text { criteria }\end{array}$ & $\begin{array}{l}\text { Birthweigh } \\
\text { Cases/Con } \\
\text { (g), Ges- } \\
\text { tational } \\
\text { age } \\
\text { Cases/Con } \\
\text { (wks) }\end{array}$ \\
\hline $\begin{array}{l}\text { King et al. } \\
2013\end{array}$ & Cohort & Ireland & $27-37$ & 6 weeks & $\begin{array}{l}\text { Women } \\
\text { who gave } \\
\text { birth to } \\
\text { an infant } \\
\text { with a } \\
\text { BW } \\
<10 \text { th } \\
\text { centile } \\
\text { (n=23) } \\
\text { Subse- } \\
\text { quently } \\
\text { classified } \\
\text { as } \\
\text { Preeclamp- } \\
\text { sia/ GH = } \\
3\end{array}$ & $\begin{array}{l}\text { Women } \\
\text { who gave } \\
\text { birth to } \\
\text { an infant } \\
\text { with a } \\
\text { BW [?] } \\
\text { 10th } \\
\text { centile (n } \\
=23 \text { ) } \\
\text { Subse- } \\
\text { quently } \\
\text { classified } \\
\text { as } \\
\text { Preeclamp- } \\
\text { sia/GH = } \\
2\end{array}$ & $\begin{array}{l}\text { Pre- } \\
\text { existing } \\
\text { diabetes } \\
\text { mellitus, } \\
\text { hyperten- } \\
\text { sion, CVD } \\
\text { GDM, } \\
\text { smoking, } \\
\text { significant } \\
\text { medi- } \\
\text { cal/psychiatr } \\
\text { illness }\end{array}$ & $\begin{array}{l}\text { BW } \\
\text { Case:2.34 } \\
(2.13-2.65) \\
\text { Con:3.6 } \\
(3.17-3.85) \\
\text { GA } \\
\text { Case:271 } \\
(260-278) \\
\text { Con:278 } \\
(270-286) \\
\text { ic }\end{array}$ \\
\hline
\end{tabular}




\begin{tabular}{|c|c|c|c|c|c|c|c|c|}
\hline Study & $\begin{array}{l}\text { Study } \\
\text { design }\end{array}$ & Country & Age & $\begin{array}{l}\text { Post } \\
\text { partum } \\
\text { follow up } \\
\text { time }\end{array}$ & $\begin{array}{l}\text { Inclusion } \\
\text { criteria: } \\
\text { Cases }\end{array}$ & $\begin{array}{l}\text { Inclusion } \\
\text { criteria: } \\
\text { Controls }\end{array}$ & $\begin{array}{l}\text { Exclusion } \\
\text { criteria }\end{array}$ & $\begin{array}{l}\text { Birthweight } \\
\text { Cases/Contro } \\
\text { (g), Ges- } \\
\text { tational } \\
\text { age } \\
\text { Cases/Contra } \\
\text { (wks) }\end{array}$ \\
\hline $\begin{array}{l}\text { Fraser et } \\
\text { al. } 2012\end{array}$ & Cohort & UK & $\begin{array}{l}\text { Approx. } \\
42-52\end{array}$ & 18 years & $\begin{array}{l}\text { Women } \\
\text { who gave } \\
\text { birth to } \\
\text { an infant } \\
\text { with a } \\
\text { BW } \\
<10 \text { th } \\
\text { centile (n } \\
=262)\end{array}$ & $\begin{array}{l}\text { Women } \\
\text { who gave } \\
\text { birth to } \\
\text { an infant } \\
\text { with a } \\
\text { BW } \\
\text { between } \\
10^{\text {th }}-90^{\text {th }} \\
\text { centile (n } \\
=2630)\end{array}$ & $\mathrm{N} / \mathrm{A}$ & $\mathrm{N} / \mathrm{A}$ \\
\hline
\end{tabular}




\begin{tabular}{|c|c|c|c|c|c|c|c|c|}
\hline Study & $\begin{array}{l}\text { Study } \\
\text { design }\end{array}$ & Country & Age & $\begin{array}{l}\text { Post } \\
\text { partum } \\
\text { follow up } \\
\text { time }\end{array}$ & $\begin{array}{l}\text { Inclusion } \\
\text { criteria: } \\
\text { Cases }\end{array}$ & $\begin{array}{l}\text { Inclusion } \\
\text { criteria: } \\
\text { Controls }\end{array}$ & $\begin{array}{l}\text { Exclusion } \\
\text { criteria }\end{array}$ & $\begin{array}{l}\text { Birthweight } \\
\text { Cases/Contro } \\
\text { (g), Ges- } \\
\text { tational } \\
\text { age } \\
\text { Cases/Contra } \\
\text { (wks) }\end{array}$ \\
\hline $\begin{array}{l}\text { Low } \\
\text { birth- } \\
\text { weight } \\
\text { (LBW) }\end{array}$ & $\begin{array}{l}\text { Low } \\
\text { birth- } \\
\text { weight } \\
\text { (LBW) }\end{array}$ & $\begin{array}{l}\text { Low } \\
\text { birth- } \\
\text { weight } \\
\text { (LBW) }\end{array}$ & $\begin{array}{l}\text { Low } \\
\text { birth- } \\
\text { weight } \\
\text { (LBW) }\end{array}$ & $\begin{array}{l}\text { Low } \\
\text { birth- } \\
\text { weight } \\
\text { (LBW) }\end{array}$ & $\begin{array}{l}\text { Low } \\
\text { birth- } \\
\text { weight } \\
\text { (LBW) }\end{array}$ & $\begin{array}{l}\text { Low } \\
\text { birth- } \\
\text { weight } \\
\text { (LBW) }\end{array}$ & $\begin{array}{l}\text { Low } \\
\text { birth- } \\
\text { weight } \\
\text { (LBW) }\end{array}$ & $\begin{array}{l}\text { Low } \\
\text { birth- } \\
\text { weight } \\
\text { (LBW) }\end{array}$ \\
\hline
\end{tabular}




\begin{tabular}{|c|c|c|c|c|c|c|c|c|}
\hline Study & $\begin{array}{l}\text { Study } \\
\text { design }\end{array}$ & Country & Age & $\begin{array}{l}\text { Post } \\
\text { partum } \\
\text { follow up } \\
\text { time }\end{array}$ & $\begin{array}{l}\text { Inclusion } \\
\text { criteria: } \\
\text { Cases }\end{array}$ & $\begin{array}{l}\text { Inclusion } \\
\text { criteria: } \\
\text { Controls }\end{array}$ & $\begin{array}{l}\text { Exclusion } \\
\text { criteria }\end{array}$ & $\begin{array}{l}\text { Birthweigh } \\
\text { Cases/Con } \\
\text { (g), Ges- } \\
\text { tational } \\
\text { age } \\
\text { Cases/Con } \\
\text { (wks) }\end{array}$ \\
\hline
\end{tabular}




\begin{tabular}{|c|c|c|c|c|c|c|c|c|}
\hline Study & $\begin{array}{l}\text { Study } \\
\text { design }\end{array}$ & Country & Age & $\begin{array}{l}\text { Post } \\
\text { partum } \\
\text { follow up } \\
\text { time }\end{array}$ & $\begin{array}{l}\text { Inclusion } \\
\text { criteria: } \\
\text { Cases }\end{array}$ & $\begin{array}{l}\text { Inclusion } \\
\text { criteria: } \\
\text { Controls }\end{array}$ & $\begin{array}{l}\text { Exclusion } \\
\text { criteria }\end{array}$ & $\begin{array}{l}\text { Birthweigh } \\
\text { Cases/Con } \\
\text { (g), Ges- } \\
\text { tational } \\
\text { age } \\
\text { Cases/Con } \\
(w k s)\end{array}$ \\
\hline $\begin{array}{l}\text { Lawlor et } \\
\text { al. } 2002\end{array}$ & $\begin{array}{l}\text { Cross } \\
\text { sectional } \\
\text { survey }\end{array}$ & UK & $68.1-69.4$ & $\mathrm{~N} / \mathrm{A}$ & $\begin{array}{l}3265 \\
\text { randomly } \\
\text { selected } \\
\text { women. } \\
\text { Details of } \\
\text { pregnancy } \\
\text { obtained } \\
\text { at } \\
\text { interview } \\
\text { and blood } \\
\text { samples } \\
\text { taken for } \\
\text { assess- } \\
\text { ment of } \\
\text { insulin. } \\
\text { Women } \\
\text { groups } \\
\text { according } \\
\text { to BW of } \\
\text { first child } \\
\text { as } 1.56- \\
2.94 \mathrm{~kg} \text {, } \\
2.95- \\
3.26 \mathrm{~kg} \text {, } \\
3.27- \\
3.58 \mathrm{~kg}, \\
3.59- \\
4.98 \mathrm{~kg}\end{array}$ & $\begin{array}{l}3265 \\
\text { randomly } \\
\text { selected } \\
\text { women. } \\
\text { Details of } \\
\text { pregnancy } \\
\text { obtained } \\
\text { at } \\
\text { interview } \\
\text { and blood } \\
\text { samples } \\
\text { taken for } \\
\text { assess- } \\
\text { ment of } \\
\text { insulin. } \\
\text { Women } \\
\text { groups } \\
\text { according } \\
\text { to BW of } \\
\text { first child } \\
\text { as } 1.56- \\
2.94 \mathrm{~kg} \text {, } \\
2.95- \\
3.26 \mathrm{~kg} \text {, } \\
3.27- \\
3.58 \mathrm{~kg}, \\
3.59- \\
4.98 \mathrm{~kg}\end{array}$ & $\begin{array}{l}3265 \\
\text { randomly } \\
\text { selected } \\
\text { women. } \\
\text { Details of } \\
\text { pregnancy } \\
\text { obtained } \\
\text { at } \\
\text { interview } \\
\text { and blood } \\
\text { samples } \\
\text { taken for } \\
\text { assess- } \\
\text { ment of } \\
\text { insulin. } \\
\text { Women } \\
\text { groups } \\
\text { according } \\
\text { to BW of } \\
\text { first child } \\
\text { as } 1.56- \\
2.94 \mathrm{~kg} \text {, } \\
2.95- \\
3.26 \mathrm{~kg} \text {, } \\
3.27- \\
3.58 \mathrm{~kg} \text {, } \\
3.59- \\
4.98 \mathrm{~kg}\end{array}$ & $\begin{array}{l}3265 \\
\text { randomly } \\
\text { selected } \\
\text { women. } \\
\text { Details of } \\
\text { pregnancy } \\
\text { obtained } \\
\text { at } \\
\text { interview } \\
\text { and blood } \\
\text { samples } \\
\text { taken for } \\
\text { assess- } \\
\text { ment of } \\
\text { insulin. } \\
\text { Women } \\
\text { groups } \\
\text { according } \\
\text { to BW of } \\
\text { first child } \\
\text { as } 1.56- \\
2.94 \mathrm{~kg} \text {, } \\
2.95- \\
3.26 \mathrm{~kg} \text {, } \\
3.27- \\
3.58 \mathrm{~kg} \text {, } \\
3.59- \\
4.98 \mathrm{~kg}\end{array}$ \\
\hline
\end{tabular}




\begin{tabular}{|c|c|c|c|c|c|c|c|}
\hline Study & $\begin{array}{l}\text { Study } \\
\text { design }\end{array}$ & Country & Age & $\begin{array}{l}\text { Post } \\
\text { partum } \\
\text { follow up } \\
\text { time }\end{array}$ & $\begin{array}{l}\text { Inclusion } \\
\text { criteria: } \\
\text { Cases }\end{array}$ & $\begin{array}{l}\text { Inclusion } \\
\text { criteria: } \\
\text { Controls }\end{array}$ & $\begin{array}{l}\text { Exclusion } \\
\text { criteria }\end{array}$ \\
\hline $\begin{array}{l}\text { Manten et } \\
\text { al. } 2007\end{array}$ & $\begin{array}{l}\text { Case } \\
\text { Control }\end{array}$ & $\begin{array}{l}\text { The } \\
\text { Netherlands }\end{array}$ & $\begin{array}{l}\text { Approx. } \\
27-37\end{array}$ & $\begin{array}{l}3-25 \\
\text { months }\end{array}$ & $\begin{array}{l}\text { Women } \\
\text { who gave } \\
\text { birth to } \\
\text { an infant } \\
\text { with BW } \\
<5 \text { th } \\
\text { percentile } \\
\text { for the } \\
\text { Dutch } \\
\text { population } \\
\text { and } \\
\text { delivery < } \\
34 \text { weeks' } \\
\text { gestation } \\
\text { due to } \\
\text { fetal } \\
\text { distress } \\
\text { (n=59) } \\
\text { Chronic } \\
\text { hyperten- } \\
\text { sion = } \\
5\end{array}$ & $\begin{array}{l}\text { Women } \\
\text { who had } \\
\text { uncompli- } \\
\text { cated } \\
\text { pregnan- } \\
\text { cies } \\
(\mathrm{n}=53)\end{array}$ & $\mathrm{N} / \mathrm{A}$ \\
\hline
\end{tabular}




\begin{tabular}{|c|c|c|c|c|c|c|c|c|}
\hline Study & $\begin{array}{l}\text { Study } \\
\text { design }\end{array}$ & Country & Age & $\begin{array}{l}\text { Post } \\
\text { partum } \\
\text { follow up } \\
\text { time }\end{array}$ & $\begin{array}{l}\text { Inclusion } \\
\text { criteria: } \\
\text { Cases }\end{array}$ & $\begin{array}{l}\text { Inclusion } \\
\text { criteria: } \\
\text { Controls }\end{array}$ & $\begin{array}{l}\text { Exclusion } \\
\text { criteria }\end{array}$ & $\begin{array}{l}\text { Birthweig } \\
\text { Cases/Co } \\
\text { (g), Ges- } \\
\text { tational } \\
\text { age } \\
\text { Cases/Co } \\
\text { (wks) }\end{array}$ \\
\hline $\begin{array}{l}\text { Yinon et } \\
\text { al. } 2010\end{array}$ & $\begin{array}{l}\text { Case } \\
\text { Control }\end{array}$ & Canada & $\begin{array}{l}\text { Approx. } \\
31-36\end{array}$ & $\begin{array}{l}6-24 \\
\text { months }\end{array}$ & $\begin{array}{l}\text { Normotens } \\
\text { IUGR } \\
\text { Women } \\
\text { who gave } \\
\text { birth to } \\
\text { an infant } \\
\text { with BW } \\
<5 \text { th } \\
\text { percentile } \\
\text { accompa- } \\
\text { nied by } \\
\text { abnormal } \\
\text { umbilical } \\
\text { artery } \\
\text { Doppler } \\
\text { (absence } \\
\text { or reverse } \\
\text { of end } \\
\text { diastolic } \\
\text { velocity) } \\
\text { in the } \\
\text { absence of } \\
\text { hyperten- } \\
\text { sive } \\
\text { disease in } \\
\text { pregnancy } \\
\text {-n=9 All } 9 \\
\text { had severe } \\
\text { IUGR and } \\
\text { were } \\
\text { delivered } \\
<34 \\
\text { weeks' } \\
\text { gestation }\end{array}$ & $\begin{array}{l}\text { eWomen } \\
\text { who had } \\
\text { uncompli- } \\
\text { cated } \\
\text { pregnan- } \\
\text { cies } \\
(\mathrm{n}=16)\end{array}$ & $\begin{array}{l}\text { Current or } \\
\text { past } \\
\text { hyperten- } \\
\text { sion, } \\
\text { diabetes } \\
\text { mellitus, } \\
\text { pregesta- } \\
\text { tional } \\
\text { renal } \\
\text { disease, } \\
\text { BMI } \\
>30 k g / m 2, \\
\text { multiple } \\
\text { gestation } \\
\text { in index } \\
\text { pregnancy, } \\
\text { smoking, } \\
\text { those } \\
\text { living with } \\
\text { smokers, } \\
\text { those } \\
\text { using oral } \\
\text { contracep- } \\
\text { tive } \\
\text { pill }\end{array}$ & $\begin{array}{l}\text { BW Case: } \\
841 \pm 133 \\
\text { Con: } 3417 \\
\pm 88 \text { GA } \\
\text { Case: } 29.2 \\
\pm 0.9 \\
\text { Con: } 39.6 \\
\pm 0.3\end{array}$ \\
\hline
\end{tabular}




\begin{tabular}{|c|c|c|c|c|c|c|c|c|}
\hline Study & $\begin{array}{l}\text { Study } \\
\text { design }\end{array}$ & Country & Age & $\begin{array}{l}\text { Post } \\
\text { partum } \\
\text { follow up } \\
\text { time }\end{array}$ & $\begin{array}{l}\text { Inclusion } \\
\text { criteria: } \\
\text { Cases }\end{array}$ & $\begin{array}{l}\text { Inclusion } \\
\text { criteria: } \\
\text { Controls }\end{array}$ & $\begin{array}{l}\text { Exclusion } \\
\text { criteria }\end{array}$ & $\begin{array}{l}\text { Birthweight } \\
\text { Cases/Contro } \\
\text { (g), Ges- } \\
\text { tational } \\
\text { age } \\
\text { Cases/Contre } \\
\text { (wks) }\end{array}$ \\
\hline
\end{tabular}

Table 2 Published studies of the association between offspring size at birth and maternal cardiovascular disease mortality 


\begin{tabular}{|c|c|c|c|c|c|c|}
\hline Study & $\begin{array}{l}\text { Study } \\
\text { design }\end{array}$ & Country & Follow up & Population & $\begin{array}{l}\text { Outcome } \\
\text { measures } \\
\text { reported }\end{array}$ & $\begin{array}{l}\text { Significant } \\
\text { findings }\end{array}$ \\
\hline $\begin{array}{l}\text { Davey Smith } \\
\text { et al. } 1997\end{array}$ & $\begin{array}{l}\text { Record linkage } \\
\text { study }\end{array}$ & Scotland & 15 years & $\begin{array}{l}794 \text { married } \\
\text { couples from } \\
\text { the west of } \\
\text { Scotland }\end{array}$ & $\begin{array}{l}\text { CVD } \\
\text { mortality }\end{array}$ & $\begin{array}{l}\text { For } 1 \mathrm{~kg} \\
\text { decrease in } \\
\text { offspring BW, } \\
\text { HR = 2.0 } \\
(95 \% \text { CI, } 1.18 \text {, } \\
3.33) \text { For } 1 \\
\text { quartile } \\
\text { increase in } \\
\text { offspring BW, } \\
\text { HR = 0.83 } \\
(95 \% \text { CI, 0.68, } \\
\text { 1.02) Adjusted } \\
\text { for offspring } \\
\text { sex, parental } \\
\text { age } \\
\text { Adjustment } \\
\text { for blood } \\
\text { pressure, } \\
\text { cholesterol, } \\
\text { body mass } \\
\text { index, } \\
\text { smoking, } \\
\text { social class, } \\
\text { area } \\
\text { deprivation, } \\
\text { lung function, } \\
\text { bronchitis, } \\
\text { angina and } \\
\text { ECG evidence } \\
\text { of CHD at } \\
\text { baseline had } \\
\text { only modest } \\
\text { effects on the } \\
\text { point } \\
\text { estimates but } \\
\text { reduced the } \\
\text { statistical } \\
\text { significance }\end{array}$ \\
\hline
\end{tabular}




\begin{tabular}{|c|c|c|c|c|c|c|}
\hline Study & $\begin{array}{l}\text { Study } \\
\text { design }\end{array}$ & Country & Follow up & Population & $\begin{array}{l}\text { Outcome } \\
\text { measures } \\
\text { reported }\end{array}$ & $\begin{array}{l}\text { Significant } \\
\text { findings }\end{array}$ \\
\hline $\begin{array}{l}\text { Davey Smith } \\
\text { et al. } 2000\end{array}$ & $\begin{array}{l}\text { Record linkage } \\
\text { study }\end{array}$ & UK & 10 years & $\begin{array}{l}\text { Information } \\
\text { from birth } \\
\text { registrations of } \\
\text { infants during } \\
1976-97 \text { is } \\
\text { linked to data } \\
\text { from the } \\
\text { census and } \\
\text { death } \\
\text { registration. } \\
\text { Data from } \\
44,813 \text { women } \\
\text { aged } 15-45 \\
\text { years at birth } \\
\text { registration. }\end{array}$ & $\begin{array}{l}\text { CVD } \\
\text { mortality }\end{array}$ & $\begin{array}{l}\text { For } 1 \mathrm{~kg} \\
\text { decrease in } \\
\text { offspring BW } \\
\mathrm{HR}=2.22 \\
(95 \% \mathrm{CI}, 1.46, \\
3.38) \text { (adjusted } \\
\text { for maternal } \\
\text { age SES and } \\
\text { marital } \\
\text { status). }\end{array}$ \\
\hline $\begin{array}{l}\text { Davey Smith } \\
\text { et al. } 2000\end{array}$ & $\begin{array}{l}\text { Record linkage } \\
\text { study }\end{array}$ & Finland & 34 years & $\begin{array}{l}3706 \text { women } \\
\text { who gave birth } \\
\text { to live born } \\
\text { singletons } \\
\text { between } 1954 \\
\text { - } 1963 \text { and } \\
\text { followed up } \\
\text { through the } \\
\text { Finnish } \\
\text { Central } \\
\text { population } \\
\text { and cause of } \\
\text { death } \\
\text { registries }\end{array}$ & $\begin{array}{l}\text { CVD } \\
\text { mortality }\end{array}$ & $\begin{array}{l}\text { For 1SD } \\
\text { increase in } \\
\text { offspring BW } \\
\mathrm{HR}=0.77 \\
(95 \% \mathrm{CI}, 0.65 \text {, } \\
0.90) \text { Adjusted } \\
\text { for maternal } \\
\text { age, height, } \\
\text { marital status, } \\
\text { use of private } \\
\text { health care } \\
\text { during } \\
\text { pregnancy, use } \\
\text { of hormones } \\
\text { during } \\
\text { pregnancy and } \\
\text { offspring sex }\end{array}$ \\
\hline
\end{tabular}




\begin{tabular}{|c|c|c|c|c|c|c|}
\hline Study & $\begin{array}{l}\text { Study } \\
\text { design }\end{array}$ & Country & Follow up & Population & $\begin{array}{l}\text { Outcome } \\
\text { measures } \\
\text { reported }\end{array}$ & $\begin{array}{l}\text { Significant } \\
\text { findings }\end{array}$ \\
\hline $\begin{array}{l}\text { Smith et al. } \\
2001\end{array}$ & $\begin{array}{l}\text { Record linkage } \\
\text { study }\end{array}$ & Scotland & $\mathrm{N} / \mathrm{A}$ & $\begin{array}{l}\text { Routine } \\
\text { discharge data } \\
\text { of all singleton } \\
\text { births in } \\
\text { Scotland } \\
\text { between } \\
1981-1985 \\
\text { linked to } \\
\text { mothers' } \\
\text { subsequent } \\
\text { admissions } \\
\text { and deaths at } \\
15-19 \text { years } \\
\text { follow up (129, } \\
920 \text { women) }\end{array}$ & $\begin{array}{l}\text { CHD } \\
\text { mortality }\end{array}$ & $\begin{array}{l}\text { For CHD } \\
\text { mortality } \\
\text { comparing the } \\
\text { lowest fifth of } \\
\text { offspring BW } \\
\text { with the } \\
\text { highest four } \\
\text { fifth: HR = } \\
2.8 \text { (95\% CI, } \\
1.5,5.2) \\
\text { Adjusted for } \\
\text { maternal age, } \\
\text { height, social } \\
\text { class and } \\
\text { preeclampsia } \\
\text { and offspring } \\
\text { sex and pre } \\
\text { term birth HR } \\
=2.4(95 \% \\
\text { CI, } 1.3,4.4)\end{array}$ \\
\hline $\begin{array}{l}\text { Davey Smith } \\
\text { et al. } 2005\end{array}$ & $\begin{array}{l}\text { Record linkage } \\
\text { study }\end{array}$ & Sweden & $\begin{array}{l}\text { Average } 20.4 \\
\text { years }\end{array}$ & $\begin{array}{l}\text { Data from the } \\
\text { Swedish } \\
\text { Medical Birth } \\
\text { register for all } \\
783,814 \\
\text { children born } \\
\text { in Sweden } \\
\text { between } 1973 \text { - } \\
1980 \text { were } \\
\text { linked with } \\
\text { parents' death } \\
\text { records } \\
\text { (783,340 } \\
\text { women) }\end{array}$ & $\begin{array}{l}\text { CVD } \\
\text { mortality } \\
\text { CHD } \\
\text { mortality }\end{array}$ & $\begin{array}{l}\text { For } 1 \mathrm{SD} \\
(0.53 \mathrm{~kg}) \\
\text { increase in } \\
\text { offspring BW, } \\
\text { Gestational } \\
\text { age adjusted } \\
\text { CVD } \\
\text { mortality, HR } \\
=0.75(0.70- \\
0.80) \\
\text { Gestational } \\
\text { age adjusted } \\
\text { CHD } \\
\text { mortality, HR } \\
=0.72(0.65- \\
0.80)\end{array}$ \\
\hline
\end{tabular}




\begin{tabular}{|c|c|c|c|c|c|c|}
\hline Study & $\begin{array}{l}\text { Study } \\
\text { design }\end{array}$ & Country & Follow up & Population & $\begin{array}{l}\text { Outcome } \\
\text { measures } \\
\text { reported }\end{array}$ & $\begin{array}{l}\text { Significant } \\
\text { findings }\end{array}$ \\
\hline $\begin{array}{l}\text { Davey Smith } \\
\text { et al. } 2007\end{array}$ & $\begin{array}{l}\text { Record linkage } \\
\text { study }\end{array}$ & UK & $26.2-27.5$ & $\begin{array}{l}12,086 \text { women } \\
\text { from the } 1958 \\
\text { British Birth } \\
\text { Cohort }\end{array}$ & $\begin{array}{l}\text { CHD } \\
\text { mortality }\end{array}$ & $\begin{array}{l}\text { CHD } \\
\text { mortality For } \\
\text { a 1-SD } \\
\text { increase in } \\
\text { BW; HR = } \\
0.80 \text { (95\% CI: } \\
0.74,0.87) \\
\text { After } \\
\text { adjustment } \\
\text { for: birth year, } \\
\text { offspring } \\
\text { gestational } \\
\text { age, social } \\
\text { class in 1958, } \\
\text { maternal } \\
\text { parity, } \\
\text { preeclamptic } \\
\text { pregnancy, } \\
\text { maternal } \\
\text { height and } \\
\text { BMI in 1958, } \\
\text { maternal } \\
\text { smoking } \\
\text { during } \\
\text { pregnancy HR } \\
=0.84(95 \% \\
\text { CI: } 0.77,0.91)\end{array}$ \\
\hline
\end{tabular}




\begin{tabular}{|c|c|c|c|c|c|c|}
\hline Study & $\begin{array}{l}\text { Study } \\
\text { design }\end{array}$ & Country & Follow up & Population & $\begin{array}{l}\text { Outcome } \\
\text { measures } \\
\text { reported }\end{array}$ & $\begin{array}{l}\text { Significant } \\
\text { findings }\end{array}$ \\
\hline $\begin{array}{l}\text { Li et al. } \\
2010\end{array}$ & Record linkage & Taiwan & 30 years & $\begin{array}{l}\text { Linkage of } \\
\text { data of } \\
1,400,383 \\
\text { women with } \\
\text { singleton } \\
\text { births } \\
\text { recorded in } \\
\text { the Taiwan } \\
\text { Birth Registry } \\
\text { between } \\
\text { 1978-2006 with } \\
\text { mortality data } \\
\text { recorded in the } \\
\text { Taiwan Death } \\
\text { Registry }\end{array}$ & $\begin{array}{l}\text { CVD } \\
\text { mortality }\end{array}$ & 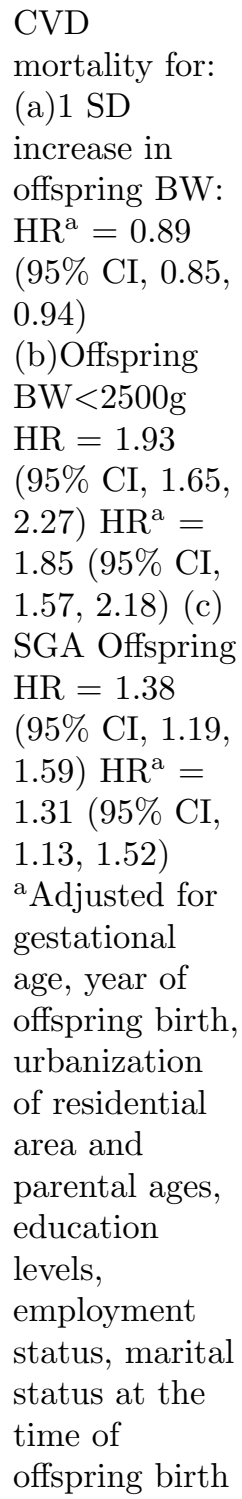 \\
\hline
\end{tabular}




\begin{tabular}{|c|c|c|c|c|c|c|}
\hline Study & $\begin{array}{l}\text { Study } \\
\text { design }\end{array}$ & Country & Follow up & Population & $\begin{array}{l}\text { Outcome } \\
\text { measures } \\
\text { reported }\end{array}$ & $\begin{array}{l}\text { Significant } \\
\text { findings }\end{array}$ \\
\hline $\begin{array}{l}\text { Pariente } \text { et } \\
\text { al. } 2013\end{array}$ & $\begin{array}{l}\text { Record linkage } \\
\text { study }\end{array}$ & Israel & $\mathrm{N} / \mathrm{A}$ & $\begin{array}{l}\text { Perinatal } \\
\text { database of } \\
\text { women who } \\
\text { delivered } \\
\text { between Jan } \\
\text { 1988-Dec } 1998 \\
\text { was linked } \\
\text { with } \\
\text { hospitalization } \\
\text { data collected } \\
\text { up until } 31 \\
\text { Dec } 2010 . \\
\text { SGA was } \\
\text { defined as BW } \\
\text { below the } 10^{\text {th }} \\
\text { population } \\
\text { centile Risk for } \\
\text { mortality due } \\
\text { to CVD } \\
\text { among those } \\
\text { who delivered } \\
\text { SGA infants } \\
\text { (n=4414) was } \\
\text { compared with } \\
\text { those who } \\
\text { delivered } \\
\text { non-SGA } \\
\text { infants } \\
\text { (n=47612) }\end{array}$ & $\begin{array}{l}\text { CVD } \\
\text { mortality }\end{array}$ & $\begin{array}{l}\text { After } \\
\text { adjusting for } \\
\text { diabetes, } \\
\text { preeclampsia } \\
\text { obesity, } \\
\text { maternal age, } \\
\text { and ethnicity, } \\
\text { SGA was } \\
\text { associated } \\
\text { with increased } \\
\text { cardiovascular } \\
\text { mortality } \\
\text { (adjusted HR } \\
3.5,95 \% \text { CI, } \\
1.5-8.2\end{array}$ \\
\hline
\end{tabular}




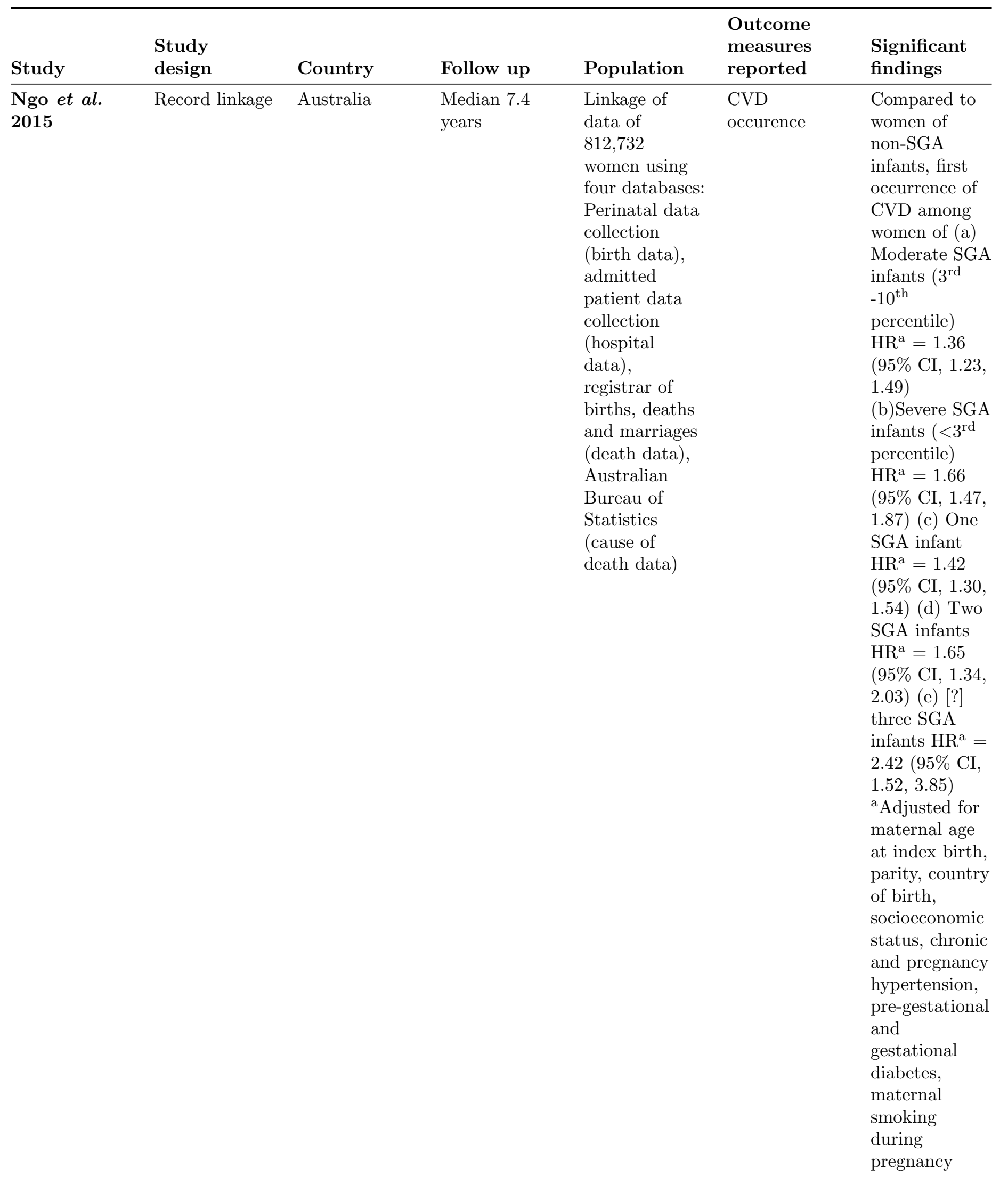




\begin{tabular}{|c|c|c|c|c|c|c|}
\hline Study & $\begin{array}{l}\text { Study } \\
\text { design }\end{array}$ & Country & Follow up & Population & $\begin{array}{l}\text { Outcome } \\
\text { measures } \\
\text { reported }\end{array}$ & $\begin{array}{l}\text { Significant } \\
\text { findings }\end{array}$ \\
\hline $\begin{array}{l}\text { Shaikh et al. } \\
2019\end{array}$ & $\begin{array}{l}\text { Record linkage } \\
\text { study }\end{array}$ & Norway & $\begin{array}{l}\text { Mean follow } \\
\text { up time } 47 \pm \\
5 \text { years Mean } \\
\text { age at follow } \\
\text { up } 55 \pm 10.4 \\
\text { years }\end{array}$ & $\begin{array}{l}\text { Linkage of } \\
\text { data from } \\
\text { cardiovascular } \\
\text { health surveys, } \\
\text { the medical } \\
\text { birth registry, } \\
\text { the cause of } \\
\text { death registry, } \\
\text { the } \\
\text { educational } \\
\text { registry and a } \\
\text { multigenera- } \\
\text { tional } \\
\text { database } \\
\text { containing } \\
\text { information on } \\
\text { familial } \\
\text { relationships } \\
\text { for the whole } \\
\text { population of } \\
\text { Norway. } \\
\text { Offspring born } \\
\text { between } \\
\text { 1967-2012 } \\
\text { were included }\end{array}$ & $\begin{array}{l}\text { CVD } \\
\text { mortality }\end{array}$ & $\begin{array}{l}\text { (a) CVD } \\
\text { mortality for } 1 \\
\text { SD increase in } \\
\text { offspring BW } \\
\text { (b) CVD } \\
\text { mortality in } \\
\text { women who } \\
\text { had SGA vs } \\
\text { AGA offspring } \\
\text { Model 1: } \\
\text { adjusted for } \\
\text { maternal age } \\
\text { at offspring } \\
\text { birth (a) HR } \\
=0.72 \text { (95\% } \\
\text { CI, 0.69, 0.75) } \\
\text { (b) HR = 2.02 } \\
\text { (95\% CI, 1.85, } \\
2.21) \text { Model } 2 \text { : } \\
\text { adjusted for } \\
\text { model 1 + } \\
\text { offspring year } \\
\text { of birth, } \\
\text { mother's } \\
\text { parity, } \\
\text { mother's } \\
\text { diseases before } \\
\text { and during } \\
\text { pregnancy, } \\
\text { diseases in } \\
\text { offspring (a) } \\
\text { HR = 0.74 } \\
\text { (95\% CI, 0.71, } \\
0.78) \text { (b) HR } \\
=1.87 \text { (95\% } \\
\text { CI, 1.71, } 2.05 \text { ) } \\
\text { Model } 3: \\
\text { adjusted for } \\
\text { model 1+2 + } \\
\text { parental } \\
\text { marital status, } \\
\text { educational } \\
\text { level in parents } \\
\text { (a) HR = 0.77 } \\
\text { (95\% CI, 0.74, } \\
0.80) \text { (b) HR } \\
=1.74 \text { (95\% } \\
\text { CI, 1.59, 1.91) }\end{array}$ \\
\hline
\end{tabular}




\begin{tabular}{|c|c|c|c|c|c|c|}
\hline Study & $\begin{array}{l}\text { Study } \\
\text { design }\end{array}$ & Country & Follow up & Population & $\begin{array}{l}\text { Outcome } \\
\text { measures } \\
\text { reported }\end{array}$ & $\begin{array}{l}\text { Significant } \\
\text { findings }\end{array}$ \\
\hline
\end{tabular}

\section{Hosted file}

Figure 1 PRISMA flow diagram of study selection process.docx available at https:// authorea.com/users/351873/articles/476315-offspring-size-at-birth-and-maternal-riskfor-cardiovascular-disease-a-systematic-review-and-meta-analysis

\section{Hosted file}

Figure 2 Cardio-metabolic risk factors between women who gave birth to infants with IUGR and women who available at https://authorea.com/users/351873/articles/476315-offspring-size-at-birth-andmaternal-risk-for-cardiovascular-disease-a-systematic-review-and-meta-analysis

\section{Hosted file}

Figure 3 Cardiovascular disease mortality between women who gave birth to SGA infants and women who gav available at https://authorea.com/users/351873/articles/476315-offspring-size-at-birth-andmaternal-risk-for-cardiovascular-disease-a-systematic-review-and-meta-analysis 